\title{
Validity of National Involvement of Indonesian National Army in The Eradication of Terrorism
}

\author{
Irman Putra, Ramlani Lina Sinaulan \\ Program Studi Magister Ilmu Hukum \\ Fakultas Hukum, Universitas Jayabaya \\ irmanputra12@gmail.com \\ ramlani_ls@jayabaya.ac.id
}

Received: 04 Januari 2021; Revised: 26 Februari 2021; Accepted: 28 April 2021

DOI: http://dx.doi.org/10.37905/aksara.7.2.681-694.2021

\begin{abstract}
Abstarak
Penelitian ini bermaksud mengkaji validitas norma pelibatan tentara nasional Indonesia dalam pemberantasan terorisme sebagaimana diatur dalam UU No. 5 Tahun 2018 dari sudut pandang konstitusi dam peraturan perundang-undangan. Untuk menganalisis masalah tersebut, digunakan teori kedaulatan negara, teori 8norma hukum dan teori kewenangan sebagai perangkat analisis. Penelitian ini menunjukan bahwa norma pelibatan TNI dalam pemberantasan terorisme sebagaimana diatur dalam UU No. 5 Tahun 2018 memiliki validitas yang kuat dalam sistem hukum nasional karena norma tersebut konsisten dengan Pancasila dan UUD 1945 sebagai norma dasar (Staatsfundamentalnorm) dan hukum dasar negara (staatsgrundgesetz) yang menjadi landasan pemberlakuan norma tersebut. Disebut valid dan konsisten karena pelibatan TNI dalam pemberantasan terorisme dibatasi pada aksi-aksi terorisme yang mengancam pertahanan negara dan kedaulatan nasional.
\end{abstract}

Kata Kunci: Validitas, Norma, Kewenangan, Militer, Terorisme.

\begin{abstract}
This study intends to examine the validity of the norms for the involvement of the Indonesian national army in the eradication of terrorism as stipulated in Law no. 5 of 2018 from the point of view of the constitution and laws and regulations. To analyze this problem, state sovereignty theory, legal norm theory and authority theory are used as analysis tools. This research shows that the norms of involving the TNI in combating terrorism as regulated in Law no. 5 of 2018 has strong validity in the national legal system because these norms are consistent with Pancasila and the 1945 Constitution as the basic norms (Staatsfundamentalnorm) and the basic law of the state (staatsgrundgesetz) which are the basis for the implementation of these norms. It is called valid and consistent because the involvement of the TNI in combating terrorism is limited to acts of terrorism that threaten national defense and national sovereignty.
\end{abstract}

Keywords: Validity, Norms, Authority, Military, Terrorism 


\section{INTRODUCTION}

On June 22, 2008, the Government of the Republic of Indonesia enacted Law Number 5 of 2018 concerning Amendments to Law Number 15 of 2003 concerning Stipulation of Government Regulations in Lieu of Law Number 1 of 2002 concerning the Eradication of Criminal Acts of Terrorism into Law. In Law no. 5 of 2018, there are several changes in norms, elimination of norms and the addition of new norms that were not previously contained in Law No. 15 of 2003. One of the new norms added to this law is the involvement of the Indonesian National Army (TNI) in the eradication of terrorism as regulated in Article 43I as follows: (1) The duties of the Indonesian National Army in overcoming acts of terrorism are part of military operations other than war. (2) In overcoming the acts of Terrorism as referred to in paragraph (1) shall be carried out in accordance with the main tasks and functions of the Indonesian National Army. (3) Further provisions regarding the implementation of overcoming acts of terrorism as referred to in paragraph (1) shall be regulated in a Presidential Regulation.

Provisions regarding the involvement of the TNI in Law no. 5 of 2018 has raised pros and cons because it is considered to have the potential to open up a broad space for TNI involvement in the realm of law enforcement. According to some circles, the approach to tackling criminal acts of terrorism in Indonesia is part of law enforcement under the authority of law enforcement officials, so that the TNI cannot enter into the realm of law enforcement because of different main tasks and functions. Military involvement in the Terrorism Law will damage the criminal justice system mechanism considering that the law places terrorism crimes as a criminal act so that the name of the law is the law on the eradication of criminal acts of terrorism and in substance the law regulates the process and enforcement mechanism. law in dealing with crimes of terrorism. The TNI is not a law enforcement apparatus, but a state defense tool, so that the arrangement for the involvement of the TNI in the legal regime that regulates criminal justice systems in dealing with terrorism is inappropriate and wrong. On the other hand, the military is of the opinion that the norm for the involvement of the TNI in Law no. 5 The year 2018 has good reasons. In their view, terrorism can not only be categorized as a mere criminal act, but can also be seen as a threat to national defense and national security. (Edy Prasetyono, 2016). Based on this point of view, eradicating terrorism is not enough with law enforcement alone, but requires handling as is the handling of threats to national defense. Therefore, the involvement of the TNI in the eradication of terrorism needs to be formulated in a regulation that specifically regulates terrorism, so that the TNI has a stronger legal basis in the exercise of this authority. The provisions of Article 43I of Law no. 5 of 2018 above basically only reaffirms the authority of the TNI in Law No. 34 of 2004 concerning the Indonesian National Army.

This provision only emphasizes that the TNI's duties in combating terrorism are part of military operations other than war (OMSP) and these tasks must be carried out in accordance with the main duties and functions of the TNI. Because the formulation of norms is general in nature, paragraph (3) states that further provisions regarding the implementation of these tasks will be regulated in a Presidential Regulation. In order to follow up on the mandate of Article 43I 
paragraph (3) of Law Number 5 of 2018, the Government is currently drafting a Presidential Regulation on the Duties of the Indonesian National Armed Forces in Overcoming Terrorism Actions. However, the drafting of this Presidential Regulation (Perpres) did not escape criticism from a number of circles. For example, the National Human Rights Commission of the Republic of Indonesia (Komnas HAM RI) on August 8, 2019 issued a press release which essentially rejected the Presidential Decree on the Draft of the Indonesian National Armed Forces in Overcoming Terrorism Actions and urged the Government to re-review the draft because it is very important. dangerous for the continuity of democracy and efforts to protect, protect and uphold human rights in Indonesia. In line with Komnas HAM, a number of civil society components also questioned the draft Presidential Decree and stated that the involvement of the TNI in combating terrorism would undermine the law enforcement process and the design of security sector reform. Based on the description above, the debate surrounding the involvement of the TNI in combating terrorism as regulated in Article 43I of Law no. 5 of 2018 is important to be studied academically. The study referred to first of all must focus on the issue of the validity of the norms for TNI involvement in the eradication of terrorism from a constitutional perspective. Without clarity regarding the validity of these norms, the debate regarding the involvement of the TNI in combating terrorism will be fulfilled by the subjectivity of each observer in accordance with their interests, position and social role in society. Therefore, it is important to analyze the validity of the norms for the involvement of the TNI in the eradication of terrorism according to the perspective of the constitution in order to obtain a common perception regarding the substance of the norms regulated in Article 43I of Law No. 5 of 2018. Without these shared perceptions, the involvement of the TNI in combating terrorism will continue to reap resistance from a number of components of civil society who think that terrorism is only related to the aspect of law enforcement. Based on the background of the problems above, the problem formulations in this study are as follows: How is the validity of the norms for TNI involvement in the eradication of terrorism in Law Number 5 of 2018 from the perspective of the constitution and laws and regulations?

\section{RESEARCH METHODS}

To answer the above questions, the researcher uses the theory of state sovereignty, the theory of legal norms and the theory of authority as analysis tools. Methodologically, this research uses the juridical-normative method which relies on primary sources or authorities, secondary source or authorities and tertiary source or authorities. These legal materials were analyzed using interpretive methods.

\section{DISCUSSION}

Analysis of the norms for the involvement of the TNI in combating terrorism must first be understood in the context of the norm system prevailing in Indonesia. As stated by Hans Kelsen, the norm system is a unit that is structured in stages and cannot be separated from one another. Kelsen described the structure of the norm system as a "hierarchy of norms" (Stufenbau), in which norms at a higher 
level authorized or delegated the formation of norms at lower levels. Kelsen calls the highest norm a "basic norm" (Grundnorm), namely the "ultimate rule" through which other norms are formed, canceled, gain and lose their validity. (Hans Kelsen, 2005) In Kelsen's view, the validity of a norm is not determined by its effectiveness or suitability to reality, but is determined by the general norm (general norm) and its conformity with the highest norm (Hans Kelsen, 2005). Kelsen's theory is known as the "legal pyramid theory" (stufentheorie), which is a theory that provides categorization or grouping of various basic legal norms that apply. Hans Nawiasky's theory was later developed by Hans Nawiasky through a theory called "theorie von stufenufbau der rechtsordnung". This theory provides an explanation of the structure of norms as follows: (1) Basic norms of the state (Staatsfundamentalnorm); (2) Basic state law (staatsgrundgesetz); (3) formal law (formell gesetz); (4) Implementing regulations and autonomous regulations (verordnung en autonome satzung) (A. Hamid A. Attamimi, 1990). In the national legal system, the types and hierarchy of legal norms are regulated in Law Number 12 of 2011 concerning the Formation of Laws and Regulations as amended by Law Number 15 of 2019 concerning Amendments to Law Number 12 of 2011 concerning the Formation of Laws and Regulations. -Invitation. In Article 7 paragraph (1) the Law is stated as follows:

(1) Types and hierarchy of Legislation consist of:

a. The 1945 Constitution of the Republic of Indonesia;

b. Decree of the People's Consultative Assembly;

c. Laws / Government Regulations in Lieu of Laws;

d. Government regulations;

e. Presidential decree;

f. Provincial Regulation; and

g. Regency / City Regional Regulations.

(2) The legal force of Legislation in accordance with the hierarchy as referred to in paragraph (1).

Thus, in the hierarchical structure of norms currently in effect, the type of legislation that has the highest position is the 1945 Constitution of the Republic of Indonesia (UUD 1945), which refers to Hans Nawiasky's theory above as the basic law of the state. (staatsgrundgesetz). The position of the 1945 Constitution as the country's basic law is explicitly stated in the provisions of Article 3 paragraph (1) of Law no. 12 of 2011 as follows: "The 1945 Constitution of the Republic of Indonesia is the basic law in the Legislation." On top of the 1945 Constitution, there is Pancasila as "the source of all sources of state law", which when referring to Hans Kelsen above is called the basic norm (Grundnorm) or the basic norm of the state (Staatsfundamentalnorm) in Hans Nawiasky's term.

As explained by Kelsen, the validity of a norm is determined by the basic norm (Grundnorm). Herbert Hart calls it a "rule of recognition", which is a criterion for assessing the validity of other rules in a legal system. The recognition rules serve to identify legal validity and classify the rank of source of law from a higher level (superior) to a lower level (subordinate). In this classification there is the highest level, which is called by Hart with the term "supreme criterion" or "ultimate rule" 
(H.L.A. Hart, 1994) (Erich Vranes, 2006). Based on the conception of Kelsen and Hart above, it can be said that "the formation of norms that are contradictory or inconsistent with higher norms can lead to norm conflicts. The term norm conflict itself is not easy to define, because the concept of legal norms has a fairly broad scope. As noted by Erich Vranes, norms have the basic functions of obligating, prohibiting and permitting according to the logic of law. Apart from these norms, which are also called "norms of conduct", there is another category, namely "norms of competence". Competency norms are norms that allow a person / state to hold the competence / authority to change the legal situation of the person / state under the authority of the competency holder. In the exercise of this competency, new norms of behavior - prohibitions, obligations and permissions - and subordinate norms of competence may be enforced. This is the reason why competence must be distinguished from mere permissions. The exercise of competence can create inappropriate prohibitions, obligations and permits if it is carried out by persons or institutions that do not have the power to exercise that competency (Erich Vranes). Thus, norm conflicts can occur at the level of "norms of conduct", namely norms related to rights and obligations, and at the level of "norms of competence", namely norms related to granting authority to institutions. certain. The difference between the concept of norms of behavior and norms of competence is very useful in analyzing the norms of authority of the TNI in eradicating terrorism and the limits of this authority in the constitutional system in Indonesia.

After the amendment to the 1945 Constitution, the existence and position of the TNI and Polri, which were previously under one umbrella institution called ABRI, have been separated both functionally and institutionally in the Indonesian constitutional system. The TNI is a state instrument that plays a role in national defense, while the National Police is a state instrument that plays a role in maintaining security and public order and enforcing the law. Article 30 paragraph (3) of the 1945 Constitution states that "The Indonesian National Army consists of the Army, Navy and Air Force as an instrument of the state in charge of defending, protecting and maintaining the integrity and sovereignty of the state." Furthermore, Article 30 paragraph (4) of the 1945 Constitution states that "the State Police of the Republic of Indonesia as a state instrument that maintains public security and order has the duty to protect, protect, serve the community, and enforce the law."

The 1945 Constitution as the basic law of the state has provided a foundation and direction in the development of the system and the administration of state defense and security. In Article 30 paragraph (1) of the 1945 Constitution, it is stated that "every citizen has the right and obligation to participate in national defense and security efforts." Furthermore, Article 30 paragraph (2) states that "State defense and security efforts are carried out through the defense and security system of the total people by the TNI and Polri, as the main force, and the people, as a supporting force." The validity of the TNI's involvement in the eradication of terrorism is basically closely related to the scope of the concept of state defense and security, on the one hand, and the concept of terrorism itself, on the other. Before explaining the concept of national defense in the national legal system, it is important to first put forward the concept of terrorism and its relationship with national defense and sovereignty. The term "terrorism" itself falls into the category 
of "essentially contested concept" because "it has created endless disputes about its proper use on the part of the user of the concept (W.B. Gallie, 1965)." As with the concepts of "democracy" (democracy), "power", "class" (class), "revolution" (revolution) and other concepts that are essentially contested, there is no generally accepted definition of terrorism (Jeff Goodwin , 2006). According to Alex Schmid and Albert Jongman, "writers have spilled nearly as much ink as perpetrators of terrorism shed (Alex P, 1998). "Until now, there is no single definition of terrorism that has received full international approval. Walter Laquer even argues that a comprehensive definition of terrorism does not exist and will never be found in the future (Walter Laqueur, 1977). According to Jack Gibb, the definition of terrorism is controversial not only because of conceptual problems, but also because the definition of terrorism proposed by certain parties tends to reflect political and ideological prejudice (ideological and political bias) (Jack P, 1989). Currently, the study of terrorism is a growing sub-field of the discipline of International Relations. However, this new field of terrorism studies has significant weaknesses, one of which relates to the concept of a terrorist organization. The conventional approach in International Relations is to treat terrorist organizations as "non-state actors" (non-state actors) in international relations. According to Faruk Ekmekci, this approach becomes problematic due to the fact that most terrorist organizations are supported or exploited by a particular country or several countries. In Ekmekci's view, "terror is nothing but war by other means" (Faruk Ekmekci, 2011). According to Ekmekci, the weakness in the study of terrorism is that terrorism is usually defined in a way that frees both countries from their own crimes that resemble terror as well as from their involvement in terrorist acts. The conventional approach in International Relations has treated terrorist organizations as "non-state actors" (Bruce Hoffman, 2005) and terrorism as a "tool of the powerless" (Mark Juergensmeyer, 2003) . But there are two major problems with this approach of "terrorists as non-state actors" and "terrorism as tools of the helpless".

The first big problem in the study of terrorism is that most definitions of theory tend to marginalize the concept of "state terrorism". The second major problem with mainstream approaches to terrorism is that it ignores the fact that most terrorist organizations are often supported or exploited by a particular country or countries. In this case, certain state support for terrorist organizations is motivated by the desire to weaken the enemy by using proxies and / or using this support as a bargaining chip against their enemies. Since advances in military technology have made modern warfare extremely costly and devastating, it is almost "unthinkable" to wage an all-out war between established countries with comparable powers as has occurred in the past (Mary Kaldor, 1993). There are important policy implications of such an analysis. The first is that the conventional approach in the study of terrorism which treats terrorist organizations as non-state actors and terrorism as a helpless tool of people cannot be defended scientifically and and cannot assist in policy. Nearly all modern terrorist organizations have been supported by at least one country and many terrorist organizations partly act as mercenaries in nation-state wars. Thus, the conventional "non-state actor" approach in International Relations regarding terrorist organizations prevents us from understanding the real strength and role of many terrorist organizations and from 
fighting terrorism effectively. Therefore, as Blakeley said, it is time to bring the country back to the study of terrorism (Ruth Blakeley, 2007). If terrorism is nothing but "war by other means" and almost all modern terrorist organizations have been supported by one country or several countries, then the involvement of the military in combating terrorism has a strong justification. The justification for the use of the military in the war on terror is closely related to the principle of state sovereignty as stated in the Westphalia agreement. The war on terror is intended to strengthen the Westphalia system which is recognized by all countries around the world. Combating terrorism through military intervention is as important as maintaining national security and realizing state sovereignty, as fighting conventional aggression to maintain territorial integrity, which has historically been the most important concern for protecting the Westphalia order. This is because terrorism movements, at some level, can involve multiple violations of state sovereignty.

The explanation above can be used as a philosophical basis to justify military involvement in combating terrorism. However, from a legal perspective, philosophical explanations alone are not sufficient to justify TNI involvement in the eradication of terrorism. The Constitution of the Republic of Indonesia expressly states that Indonesia is a state based on law. Article 1 paragraph (3) of the 1945 Constitution of the Republic of Indonesia states that "the State of Indonesia is a State of Law." In the concept of a rule of law (rechtsstaat), it is idealized that what must be the commander in the dynamics of the life of the nation and state is law, not politics or economy. Therefore, the justification for the involvement of the TNI in combating terrorism must be based on a strong juridical foundation. As mentioned earlier, the 1945 Constitution has emphasized that the TNI is a state instrument that plays a role in national defense. In this regard, Indonesia already has a juridical concept as regulated in Law Number 3 of 2002 concerning National Defense. According to Article 1 number 1 Law N0. 3 of 2002, "National defense is all efforts to defend the sovereignty of the state, the territorial integrity of the Unitary State of the Republic of Indonesia, and the safety of the entire nation from threats and disturbances to the integrity of the nation and state." Article 1 number 2 Law N0. 3 of 2002 further states that the implementation of national defense is based on a universal defense system that involves all citizens, territories and other national resources, and is prepared early by the government and is carried out in a total, integrated, directed, and continuous manner to uphold state sovereignty, territorial integrity, and the safety of the entire nation from all threats.

According to Article 7 of Law no. 3 of 2002, the state defense system was built in order to deal with military and non-military threats. The national defense system in facing military threats places the TNI as the main component supported by a reserve component and a supporting component. Meanwhile, the state defense system in facing non-military threats places government institutions outside the field of defense as the main element, in accordance with the form and nature of the threats faced supported by other elements of the nation's power. In the elucidation of Article 7 paragraph (2) of Law no. 3 of 2002 states that what is meant by military threats is a threat using organized armed force which is considered to have the ability to endanger the sovereignty of the state, the territorial integrity of the country and the safety of the entire nation. One of the military threats is "armed terror acts 
carried out by international terrorism networks or in collaboration with domestic terrorism or domestic terrorism which has a high escalation that endangers the sovereignty of the country, territorial integrity and the safety of the entire nation." Based on these provisions, it can be said that the TNI has the authority to eradicate acts of terrorism, especially armed terrorism committed by international terrorism networks or in collaboration with domestic terrorism or high-escalating domestic terrorism that endangers the sovereignty of the state, territorial integrity and safety. the whole nation. In this context, the concept of terrorism is understood as a form of international crime that poses a threat to the integrity and sovereignty of the state. Thus, the eradication of terrorism in this conception is included in the territory of state defense, so that the authority of the TNI in this case is included in the main duties of the TNI in the scope of non-war military operations (OMSP) as regulated in Article 7 paragraph (2) letter b number 3 of the Law. No. 34 of 2004 concerning the TNI. The duties of the OMSP itself include the following:

1. Overcoming the armed separatist movement.

2. overcome armed rebellion.

3. Overcoming acts of terrorism.

4. securing the border area.

5. securing national vital objects that are strategic in nature.

6. carry out the task of world peace in accordance with foreign policy policies.

7. securing the President and vice president and their families.

8. Early empowerment of defense areas and supporting forces in accordance with the universal defense system.

9. assisting government tasks in the regions.

10. assisting the police of the Republic of Indonesia in the context of the task of security and public order as regulated in law.

11. help secure head-level state guests and representatives of foreign governments who are currently in Indonesia.

12. help cope with the consequences of natural disasters, evacuation, and provide humanitarian assistance.

13. assist in search and rescue in accidents (search and rescue).

14. assisting the government in securing shipping and aviation against piracy, piracy and smuggling.

Referring to the provisions of Article 7 paragraph (2) letter b number 3 of Law no. 34 of 2004 regarding the TNI above, the task of the TNI in overcoming acts of terrorism is a main task, not a task of assisting any agency. The implementation of tasks mandated in numbers 1 to 8 - which includes the task of overcoming acts of terrorism - is different from the tasks listed in numbers 9 to 14 . The duties of OMSP listed in numbers 1 to 8 are the main duties of the TNI so could be included in the TNI's operational plan because it directly threatened the country's sovereignty, territorial integrity, national safety and spilled Indonesian blood. Thus, overcoming international terrorism is the main task of the TNI. On the other hand, the OMSP tasks listed in numbers 9 to 14 are assistance tasks, in which the TNI is assigned to provide assistance to the mentioned agencies. Based on this Law, it is clear that the TNI can and must play an active role in overcoming acts of terrorism, so that juridically, if there is an act of terrorism that has the potential to threaten the 
sovereignty of the state and the integrity of the nation, the TNI has the authority to carry out acts of eradicating terrorism as part of military operations. other than war (OMSP) or known as "military operations other than war" (MOOTW). Based on the explanation above, the authority of the TNI in combating terrorism that is international in scope and has the potential to threaten the sovereignty of the state has strong validity, because this authority is in line with and consistent with what Erich Vranes calls the term "norm of competence", namely norms of competence. which allows a person / institution to hold the competence / authority to change the legal situation of the person / institution that is under the authority of the competency holder. In this context, the norm of authority referred to is the norm regarding the authority of the TNI as stipulated in the constitution and statutory regulations, which position the TNI as a means of state defense. The authority of the TNI in this context is clearly attributive, not delegative and mandatory. It is called attributive because this authority is determined normatively by the constitution and laws and regulations, not delegations or mandates from certain government agencies (J.G. Brouwer and A.E. Schilder, 1998).

However, this conclusion will become an arena for debate if the concept of terrorism is understood within the scope of national security. This is caused by several factors as follows. First, in various scientific literature, the concept of national security is understood differently so that there is no single and monolithic definition of what is meant by state security. Second, until now Indonesia does not yet have a juridical concept regarding national security because there is no specific law regulating national security. Third, in statutory regulations, the security function is more identical to the duties of the police as stipulated in Law no. 2 of 2002. Differences in perceptions about the concept of national security also occur in the context of the relationship between the TNI and Polri. Until now, there are still differences in interpretation between national security which is the duty of all components of the nation including the TNI and public order and security which is the duty of the Police which is interpreted as overall security, so that all security becomes the duty of the Police, defense becomes the duty of the TNI. Thus, if terrorism is understood in terms of a national threat, the institution that has the authority to tackle terrorism is the Police. In Article 15 paragraph (2) letter $\mathrm{h}$ of Law no. 2 of 2002 concerning the National Police of the Republic of Indonesia states that one of the Polri's powers is "to cooperate with other national police in investigating and eradicating international crimes." In the elucidation of Article 15 paragraph (2) letter $h$ of Law no. 2 of 2002 states that what is meant by "international crimes" are certain crimes that are agreed to be tackled between countries, including narcotics crimes, counterfeit money, terrorism, and human trafficking. Thus, one of the powers of the Police in overcoming international crimes is terrorism. The authority of the National Police in combating terrorism has been further strengthened after the enactment of Law no. 15 of 2003 concerning the Eradication of Criminal Acts of Terrorism as amended by Law No. 5 of 2018.

After the amendment of Law no. 15 of 2003, the function of the police in combating terrorism was further strengthened, because in the amendment to the Law the scope of terrorism as a threat to national security was further clarified by 
the emergence of the term "security disturbance". This can be seen in the provisions of Article 1 point 2 of Law no. 5 of 2018 as follows:

"Terrorism is an act that uses violence or threats of violence that create an atmosphere of terror or widespread fear, which can cause mass casualties, and / or cause damage or destruction to vital strategic objects, the environment, public facilities, or international facilities. with motives of ideology, politics, or security disturbances. Referring to the definition above, the main component that has the authority to eradicate the crime of terrorism is the police, because acts of terrorism are included in the spectrum of threats that can cause "security disturbances" which are included in the realm of criminal law. However, the definition also includes the phrase "ideological and political motives". This phrase implies that terrorism is not only motivated by criminal motives that can disrupt public security and order, but can also be motivated by ideological and political motives that have the potential to disrupt the order of government and national sovereignty. Therefore, Law no. $5 / 2018$ also gives authority to the TNI in eradicating terrorism as regulated in Article 43I. However, Law no. 5 of 2008 does not specify these tasks into an operational level, thus opening up opportunities for conflicts of authority between the TNI and Polri in the same field. Therefore, Article 43I paragraph (3) of Law no. $5 / 2018$ leaves the government to make further provisions regarding the authority of the TNI in the form of a Presidential Regulation. In other words, Law no. 5/2018 requires that the function of the TNI in eradicating terrorism must be clearly formulated and spelled out so that it does not conflict with Polri's function in the same field.

The formulation of the TNI's function in combating terrorism must be based on statutory regulations. In this regard, the TNI's function as a means of state defense has been regulated in Article 6 of Law no. 34 of 2004 as follows:

(1) TNI as a means of state defense functions as:

a. antidote against every form of military threats and armed threats from outside and within the country against the sovereignty, territorial integrity and safety of the nation;

b. taking action against every form of threat as referred to in paragraph (1) letter a; and

c. restorer of the state security condition which was disturbed due to security chaos.

(2) In carrying out the functions referred to in paragraph (1), the TNI is the main component of the state defense system.

The three functions above have been described in more detail in the national defense policy outlined by the Government c.q. Ministry of Defense of the Republic of Indonesia. In the 2015 Indonesian Defense White Paper, it is stated that national defense functions to realize and defend the entire territory of the Republic of Indonesia as one defense unit, which is able to protect the country's sovereignty, territorial integrity, and the safety of the entire nation from any threats, both those coming from outside and those arising inside. country. Efforts to realize and defend the entire territory of the Republic of Indonesia as a unit of defense are carried out in the function of deterrence, repression and recovery. 
Of the three functions, the potential for conflict of authority between the TNI and Polri in the context of eradicating terrorism is the function of repression. Therefore, the limits of the TNI's authority in carrying out its function of repression need to be emphasized. Referring to the constitution and laws and regulations as stated above, the function of repression can only be carried out by the TNI if the acts of terrorism faced have the potential to threaten the defense and sovereignty of the country. Acts of terrorism that fall into this category include:

1. Acts of terrorism against the President and Vice President and their families, former President and former Vice President and their families, as well as state guests at the level of the head of state / head of government who are in the country.

2. Acts of terrorism against Indonesian citizens and representatives of the Republic of Indonesia abroad.

3. Acts of terrorism against representative offices of foreign countries or offices of international organizations in Indonesia.

4. Actions of terrorism against strategic national vital objects, especially national vital objects that are an organic part or are included in the environment of the TNI.

5. Acts of terrorism against Indonesian ships, Indonesian aircraft inside and outside the territory of the Unitary State of the Republic of Indonesia.

6. Acts of terrorism against foreign ships and aircraft in the territory of the Republic of Indonesia.

7. Actions of terrorism in Indonesia's exclusive economic zone, regional and / or international areas in accordance with applicable international law.

8. Other Terrorism Actions that have high escalation and endanger the state ideology, state sovereignty, the territorial integrity of Indonesia, and the safety of the entire nation.

The function of prosecuting acts of terrorism as mentioned above is part of the main duties and functions of the TNI. Therefore, these actions can be carried out by the TNI directly, especially in the category of acts of terrorism in the first to seventh points. In this case, prosecution is carried out by TNI units assigned to carry out special operations and / or other TNI units. Such action can be carried out in the form of arrest, ambush and attack against acts of terrorism. In taking action against these acts of terrorism, the TNI coordinates with the agency in charge of counterterrorism affairs (BNPT), the Indonesian National Police (Polri), and related ministries / agencies.

Meanwhile for the category of acts of terrorism in the eighth point, namely other acts of terrorism that have high escalation and endanger the state ideology, state sovereignty, the territorial integrity of Indonesia, and the safety of the entire nation, prosecution by the TNI must be carried out based on the results of coordination with the Indonesian National Police, TNI, and the agency that manages the countermeasures for terrorism (BNPT). In this case, the determination of "high escalation" is carried out jointly by the Indonesian National Police (Polri), the TNI, and the agency in charge of counter-terrorism affairs (BNPT). In connection with this enforcement function, there are several important points that need to be raised. First, the action carried out by the TNI is limitative, that is, the 
TNI only has the authority to deal with acts of terrorism directly in the 7 (seven) categories as stated above. The seven categories are included in acts of terrorism that have the potential to threaten the defense and sovereignty of the country. Apart from the seven categories of acts of terrorism above, there are other categories of terrorism that fall under the joint authority of the TNI and Polri, namely acts of terrorism that have high escalation and endanger state ideology, national security, public order and the safety of citizens. For this category, the TNI is not authorized to take direct action, but must be carried out based on the results of coordination with the Indonesian National Police, the TNI, and the agency in charge of counterterrorism affairs (BNPT). Second, the prosecution carried out by the TNI was not pro justitia in nature, but was of a temporary nature. Thus, after the TNI takes action against the perpetrators of terrorism, whether in the form of arrest, ambush or assault, the perpetrators of terrorism are immediately handed over to the Police to undergo a legal process. In other words, the results of prosecution must be immediately submitted to the Police to be followed up with a legal process in accordance with the provisions of laws and regulations. Thus, the TNI does not interfere at all in the law enforcement process. This is very different from the views of a number of circles who argue that the involvement of the TNI in combating terrorism will undermine the law enforcement process and the design of security sector reform. On the other hand, the involvement of the TNI in eradicating terrorism in no way reduces the function of the Police as a law enforcement apparatus, because the investigation and investigation functions are still carried out by the Police. Thus, the involvement of the TNI in combating terrorism does not enter the realm of the criminal justice system.

\section{CONLUSION}

The norms for the involvement of the TNI in combating terrorism as stipulated in Law no. 5 of 2018 has strong validity in the national legal system because these norms are consistent with Pancasila and the 1945 Constitution as the basic norms (Staatsfundamentalnorm) and the basic law of the state (staatsgrundgesetz) which are the basis for the implementation of these norms. It is called valid and consistent because the involvement of the TNI in combating terrorism is limited to acts of terrorism that threaten the integrity and sovereignty of the country. This is in line with the provisions of Article 30 paragraph (3) of the 1945 Constitution which states that the TNI is an instrument of the state whose task is to defend, protect and maintain the integrity and sovereignty of the state.

In the perspective of Law 3 of 2002 concerning State Defense, armed terror acts carried out by international terrorism networks or in collaboration with domestic terrorism or domestic terrorism that have high escalation that endanger state sovereignty, territorial integrity and the safety of the entire nation are included in the category military threats, in which the TNI is the main component in dealing with these threats. In the perspective of Law no. 3 of 2004 concerning the TNI, the involvement of the TNI in the eradication of terrorism is included in the main duties of the TNI in the scope of non-war military operations (OMSP) as regulated in Article 7 paragraph (2) letter b number 3 of Law no. 34 of 2004 concerning the 
TNI. In that Article it is stated that the task of the TNI in "overcoming acts of terrorism" is a main task, not a task of assisting any agency.

Thus, the norms of involving the TNI in eradicating terrorism which have the potential to threaten the sovereignty of the state have strong validity because these norms are consistent with the "norms of authority" (norm of competence). The TNI's authority in this case is attributive, not delegative and mandatory. It is called attributive because the authority is determined normatively by the constitution and laws and regulations, not by delegations or mandates from certain government bodies.

\section{REFERENCES}

Attamimi, A. Hamid A., The Role of the Presidential Decree of the Republic of Indonesia in the Administration of the State; An Analytical Study of Presidential Decrees with Regulatory Function in the Period of Pelita I Pelita IV, Dissertation of the Faculty of Law, Postgraduate University of Indonesia, Jakarta, 1990.

Blakeley, Ruth, "Bringing the State Back into Terrorism Studies," 6: 3 European Political Science (2007).

Brouwer, J.G. and Schilder, A.E., A Survey of Dutch Administrative Law, Ars Aeguilibri, Nijmegen, 1998.

Byman, Daniel, Deadly Connections: States that Sponsor Terrorism, Cambridge University Press, New York, 2005.

Collier, David, (et.al.), "Essentially Contested Concepts: Debates and Applications", 11:3 Journal of Political Ideologies (October 2006).

Connelly, William, The Terms of Political Discourse, Princeton University Press, Princeton, NJ, 1993.

Ekmekci, Faruk, "Terrorism as War by Other Means: National Security and State Support for Terrorism," 54: 1 Revista Brasileira de Política Internacional (2011).

Gallie, W.B., "Essentially Contested Concepts", 56 Proceedings of the Aristotelian Society (1956).

Gibbs, Jack P., "Conceptualization of Terrorism", 54: 3 American Sociological Review (June 1989).

Goodwin, Jeff, “A Theory of Categorical Terrorism”, 84: 4 Social Forces (June 2006).

Hadjon, Philipus M., "Regarding the Authority", 12: 5-6 JURIDICA (1997).

Hart, H.L.A., The Concept of Law, Clarendon Press, Oxford, 1994, p. 105-106.

Hoffman, Bruce, Inside Terrorism, Columbia University Press, New York, 1999.

Juergensmeyer, Mark, Terror in the Mind of God: The Global Rise of Religious Violence, University of California Press, Berkeley, 2000.

Kaldor, Mary, New and Old Wars: Organized Violence in a Global Era, Polity Press, Cambridge, 1999.

Keegan, John, A History of Warfare, Knopf, New York, 1993.

Kelsen, Hans, General Theory of Law and State, Transaction Publishers, New Brunswick and London, 2005. 
Ministry of Defense of the Republic of Indonesia, Indonesian Defense White Paper 2015, Ministry of Defense of the Republic of Indonesia, Jakarta, 2015.

Komnas HAM, "Press Relase: Presidential Decree on TNI Involvement in Criminal Acts of Terrorism, Anomalies in Law Enforcement in Indonesia", https://www.komnasham.go.id/files/20190808-perpres-pel Engagementtni-dalam-takt-\$ J0DSM.pdf [accessed on 15 July 2020, 11.00].

Kompas, "Draft Presidential Decree on TNI Involvement in Combating Terrorism Criticized," https://nasional.kompas.com/read/2020/08/04/06374591/rancangperpres-pel Engagement-tni-berantas-terorisme-dikriti? accessed on 15 September 2020, 14.10].

Laqueur, Walter, Terrorism, Weidenfeld and Nicolson, London, 1977.

Nicholson, Marc, “An Essay on Terrorism," American Diplomacy, August, 2003, http://americandiplomacy.web.unc.edu/2003/08/an-essay-on-terrorism/ [accessed July 23, 2020, at 21.00].

Prasetyono, Edy, "Some Thoughts on the Revision of Law on the Eradication of Criminal Acts of Terrorism", Paper presented at the National Seminar on Human Rights Protection and Law Enforcement in Handling Crimes of Terrorism in Indonesia, organized by the Special Committee (Pansus) of the Terrorism Bill at the Nusantara I Building of the DPR. RI, Jakarta, 25 May 2016.

Schmid, Alex P. and Jongman, Albert J., Political Terrorism: A New Guide to Actors, Authors, Concepts, Data Bases, Theories, and Literature, NorthHolland, Amsterdam, 1988.

Civil Society Coalition Team for Security Sector Reform, "Notes Criticism Against Bill Amendment Law no. 15/2003 concerning the Eradication of Criminal Acts of Terrorism ", https://www.kontras.org/data/20170117_Kertas_Posisi_Koalisi_SSR_RU U_Perubah_UU_Terorisme_jf28792hb4y.pdf, [accessed 12 March 2018, 12:30].

Vranes, Erich, "The Definition of 'Norm Conflict' in International Law and Legal Theory", 17: 2 The European Journal of International Law (20 